\title{
Legal Development of Coastal Marine Management Based on the Idea of Pancasila
}

\author{
Jantje Tjiptabudy \\ Faculty of Law, Pattimura University, Indonesia. E-mail: jtjiptabudy@gmail.com
}

\begin{tabular}{l} 
ARTICLE INFO \\
\hline Keywords: \\
Coastal Marine; Customary \\
Law; Natural Resources; \\
Pancasila \\
How to cite: \\
Tjiptabudy, J. (2018). Legal \\
Development of Coastal \\
Marine Management Based \\
on the Idea of Pancasila. \\
Hasanuddin Law Review, \\
4(1): 113-122 \\
DOI: \\
10.20956/halrev.v4i1.1325 \\
\hline
\end{tabular}

\begin{abstract}
In relation to the positive law, the management of marine and coastal natural resources, there is also the rule of customary law. Customary law that still lives and develops in indigenous peoples also regulates the management system and utilization of natural resources in coastal and marine areas. Recognition of the rights of indigenous peoples is constitutionally contained in the 1945 Constitution of the State of the Republic of Indonesia where the state recognizes the existence of the Customary Law Community. In Maluku, marine potency management in general is still done traditionally known as marine customary rights that have been going on for generations but not yet fully recognized either by the government or entrepreneurs who are actually important partners in the development process.
\end{abstract}

\section{Introduction}

Natural resources such as land, petroleum, gas etc. have a very important role to the economic growth and prosperity of a State. Utilization and management has increased from year to year so that ecosystem damage in this region is increasing as well. Consequently, many developing and former communist countries engaged in the decentralization of authority in order to increase government accountability and efficiency, and to strengthen the role of local communities in natural resources management. 1

The management and utilization of natural resources, both marine natural resources and other natural resources as national economic assets, is implemented under Article 33 Paragraph (3) of the 1945 Constitution of the State of the Republic of Indonesia, which affirms that "Earth and water and natural resources contained in it is controlled by the

1 Wever, L., Glaser, M., Gorris, P., \& Ferrol-Schulte, D. (2012). Decentralization and participation in integrated coastal management: Policy lessons from Brazil and Indonesia. Ocean \& Coastal Management, $66,63-72$. 
State and used for the greatest prosperity of the people". The implementation of this constitutional provision is based on the principles of national economy as stipulated in Article 33 paragraph (4) of the 1945 Constitution of the State of the Republic of Indonesia, which asserts that:

The national economy shall be held based on economic democracy with the principles of togetherness, efficiency with justice, sustainability, environmental perception, independence, and by keeping the balance of the national economic progress and unity.

However, implementing the provisions of Article 33 of the 1945 Constitution shall be further regulated by law with due observance of principles such as fair efficiency. Thus, the existing resources must be allocated efficiently to support the healthy growth of national economy while achieving justice. Economic progress throughout the territory of the country should be considered balance and in the implementation of regional autonomy should also be maintained national economic unity. To describe the provisions of the 1945 Constitution at least some relevant laws have been ratified, namely Law Number 5 of 1960 on Basic Agrarian Law, Law Number 9 of 1985 concerning Fisheries, Law Number 24 Year 1992 regarding Spatial Planning, Law Number 23 Year 1997 on Environmental Management, Law Number 32 Year 2004 regarding Regional Government, Law Number 33 Year 2004 regarding Financial Balance of Central and Regional Government, and Law Number 27 Year 2007 on the Management of Coastal Areas and Small Islands.

Recognition of the rights of indigenous peoples is constitutionally contained in the 1945 Constitution of the Republic of Indonesia of the Republic of Indonesia which states: "The State recognizes and respects the unity of indigenous and tribal peoples along with their traditional rights as long as they are alive and in accordance with the development of society and the principle of the Unitary State of the Republic of Indonesia, as governed by law."

Hence, if observed indigenous peoples in coastal areas, marine potential management in general is done traditionally known as marine customary rights. Compared with the ulayat right to the land, it appears that customary rights over the sea as a customary tradition that has been going on for generations and is respected by indigenous peoples. This has not yet been fully recognized by both the government and the entrepreneurs who are actually important partners in the development process.

\section{Management of Natural Resources and Access to the Justice}

If examined and examined it turns out most of the laws governing the management of natural resources, sectoral governing certain development sectors, directly or indirectly related to the sea and coastal aspects. Especially related to the existence and customary rights of sea and coastal, there are some elements that mark the existence of coastal territory of coastal community:

a) The existence of certain areas of the sea where the community takes the materials for the necessities of life.

b) The ability to reach these places

c) Conducted from generation to generation.

d) Periodically done.

e) Always be maintained against any other party entering the territory without the permission of the indigenous peoples. 
The real mastery of marine and coastal areas, by indigenous peoples linked to their relationships or relationships to meet their needs over the region, is something that is hereditary from the ancestors. The authority herein is concerned with the management and utilization of natural resources, according to the principles of customary law with their own peculiarities. Some interesting cases that need to get in-depth study include the case of Bali fishermen with Banyuwangi fishermen who often disputes associated with the rights of natural resources management, especially fish on the Strait between Java and Bali. Similarly, Madurese fishermen with fishermen originating from Probolinggo who often questioned their catching area around the Java sea that led to the burning of certain fishing boats.

In Maluku, especially in Aru Islands District, often indigenous peoples' territories are accessed by fishermen or large entrepreneurs or who have large capital with various sophisticated tools, so that indigenous peoples around the coastal areas and small islands become difficult to obtain fish and resources other seas. The fishery entrepreneurs who have large capital because of pocketing permits from the government so they are free to install rumpon in the area adjacent to the indigenous peoples catchment area, so that in the end the fish resources become reduced in the catchment of indigenous peoples ${ }^{2}$ Other interesting cases, among others, occurred in the village of Ety, West Seram District, where pearl entrepreneurs casually coasted coastal areas in indigenous peoples' territories and ultimately with their business licenses, prohibit indigenous peoples from being allowed approaching the cultivation area of the pearl. Though since the first area is a source of life for traditional fishing communities to support their families from one generation to the next.

In Benjina Island, Aru Islands District, indigenous peoples no longer have access to pearl diving because the surrounding sea has been contaminated with waste from fish production. Finally, indigenous peoples resigned and could not do much so that eventually became poor in the territory ulayat / petuanan that is rich in the potential of natural resources ${ }^{3}$. Government policies that give permission to businessmen but pay less attention to the interests of indigenous peoples, especially those living in coastal areas will certainly have an impact on the lives of indigenous peoples and eventually they live in an atmosphere of uncertainty.

On the island of Saparua, Central Maluku district, there is an entrepreneur from Switzerland engaged in diving activities, who are licensed to build a cottage on a headland in the village of Paperu. Because the sea and coral reefs around the coast of the island is very beautiful and interesting so that the traditional fishermen are prohibited to go to sea around the headland on the grounds there are fish and biota are rare in the world ${ }^{4}$. Such circumstances create an imbalance because there is strong dominance from the government. In terms of constitutionally, indigenous communities are recognized for their existence, including territory (ulayat) either on the sea or on land. This implies that governments in various development policies, especially in the field of law, must remain consistent and take into account the existence and rights of indigenous peoples as a community that existed before the country was formed. Abandonment of the rights

2 Saptenno, M.J. (2003), Kajian Yuridis tentang Pengelolaan Wilayah Pesisir dan Laut. (Paper). Ambon: Faculty of Law, Pattimura University, p. 2-3.

3 Manery, B.D., et al. (1997), Pengaruh Kebijakan Pemerintah Dalam Pengelolaan Sumberdaya Alam terhadap Kehidupan Masyarakat Adat di Provinsi Maluku. Research Paper: Pattimura University in association Yayasan Sejati Jakarta, p. 46

4 Ambon Ekspres news, 22 June 2008 
and existence of indigenous peoples, will inevitably lead to imbalances, which can lead to various upheavals in the life of society, nation and state.

Conflicts of interest will inevitably arise, affecting various government policies. It is important to recognize that the government is present for the benefit of the community but government policies are often detrimental to society. If government policies conflict with the interests of the community, especially indigenous peoples, it will certainly bring negative impacts in the development process in general, and more specifically related to the management of natural resources in the sea and coastal areas.

\section{Legal Development of Sea and Coastal Management Based on the Idea of Pancasila Law}

By comparison, if we examine in depth the principal matters of scientific autonomy, essentially substantive, scientific autonomy is relative, ie not free of full value. This can be applied to legal development of marine and coastal management within the framework of national law development. In the development of national law must be based on ethical development of national law. The question that arises is why ethics is needed in the development of national law, in particular the laws of marine and coastal management?

As is known the discussion of ethics has been used as a dialogue of the great philosophers such as Socrates, Plato and Aristotle, where the value of wisdom (wisdom) is appropriate, even must be embraced someone or society. Fundamental, because ethics is also often referred to as moral philosophy is always in a cultural context. In a sense cannot be separated from the views of one's life or society concerned, and always actual, because ethics contains values that are always longed by anyone and anywhere. While the development of national law is to build the Indonesian law that originated in the personality of the Indonesian nation itself.

In modern times this law is made deliberately through a special body of law makers. Nevertheless, he cannot dismiss the community as a stakeholder in the making of the law. A century ago, A.V. Decey has already said, "True indeed it is that the existence and the alteration of human institutions must be in the sense of, or, in other words, upon the opinion of the society in which such institutions flourist." In the dynamics of social life, the ideals of law will affect and serve as a guiding principle, critics (evaluation rules) and motivating factors in the organization of law (the establishment, discovery, application of law) and legal behavior. Formulated and understood the ideals of law or facilitate its elaboration into various sets of rules of authority and rules of conduct and facilitate awake consistency in the implementation of law.

For this reason, Pancasila is the ideals of law and the source of the order of Indonesian national law. Elucidation of the 1945 Constitution of the Republic of Indonesia states that there is a connection and mutual influence between the points of thought is the source of and will provide content and animate the ideals of law and legal principles that will be realized in the basic law of the State and will become the fundamental of the applicable legal rules.

The essence and the main idea in the Preamble of the 1945 Indonesian Constitution is none other than the values or embodiments of the precepts of the five precepts of Pancasila which are the noble values and outlooks of life derived from Indonesian society that have been fought for a long time and has become the guideline in the nation and state for the people of Indonesia. Every precept of Pancasila as legal ideals, legal 
principles, philosophy of the State and the highest basic norms, according to Notonagoro $^{5}$ has the qualifications of the other four precepts described as follows:

For the first precepts: The essence of the Indonesian man against God, determined by the essence of God, as the innate nature of human creatures of God is to taklim and obedient to God; For the second precept: The human nature of Indonesia as the innate human nature of God's creatures is to meet the needs of his body and soul, his individual and social life, and the necessities of his religious life; For the third precept: The essence of the Indonesian people as the innate nature of the citizens of the Unity of Indonesia, the embodiment of the human nature of God's creature in the unity of relationship with fellow human beings God's creature is to awareness of the differences in society and the State; For the fourth precept: The human nature of Indonesia as the innate nature of the citizens of the people of Indonesia, the incarnation of the human nature of the creature of God incarnate as a human rights-rights in the relationship of living with individuals, in balance with the nature of the nature of social beings; For the fifth Precepts: The essence of the Indonesian man as the innate nature of the advocates of social justice, the explanation of the essence of human beings-God's being incarnate as human rights.

According to the Preamble of the 1945 Constitution of the State of the Republic of Indonesia, Pancasila as the legal ideals will have the basic law both written and unwritten. Or in other words will serve as a measure and testers and the foundation of the basic law which will further be the foundation for the legislation of the Republic of Indonesia. The provision is in accordance with the opinion of Gustav Radbruch ${ }^{6}$ namely that the ideals of law not only serve as a benchmark that is regulative, which is to test whether a positive law is fair or not, but also serves as a constitutive basis, namely to determine that without legal ideals then the law will lose its meaning as law. After the amendment of the 1945 Constitution of the State of the Republic of Indonesia, specifically article 33 there is the addition of two verses, namely paragraph 4 and 5 . This amendment only sharpens that the national economy is organized based on economic democracy with the principle of togetherness, efficiency, fairness, sustainability, and independence, and by maintaining a balance of progress and national economic unity.

From the above discussion it is clear that from the aspect of the substance, we Indonesian nation has a legal ideology that can determine the form and system of law itself based on cultural roots and aspirations of the Indonesian nation, not necessarily influenced by foreign elements that have values that conflict with values of Indonesian peoples. During this time according to Muladi, 7 how far the basic doctrines of the 1945 Constitution with all the reflection of its regulation, in this global life is not considered as a constraint and to what extent global aspirations in these various lives can be utilized without sacrificing national identity, in other words how to build Indonesian social structured law keeping in mind the globalization trend.

Therefore, according to the author, in the development of law, there are some things that are particularly critical specifically in the law of marine and coastal area management received attention, namely:

a) To design the legal structure of the management of marine and coastal areas as part of the development of national law;

5 Notonagoro. (1982). Beberapa Hal Mengenai Falsafah Pancasila. Jakarta: Rajawali Pers, p. 58-61.

6 Saleh, R. (1996). Pembinaan Cita Hukum dan Asas-asas Hukum Nasional. Jakarta: CV. Karya Dunia Fikir, p. 17

7 Fakrulloh, Z.A. (2000). Wajah Hukum di Era Globalisasi. Bandung: Citra Aditya Bakti, p. 52-53 
b) To overcome the legal trends of international marine and coastal area management into national sea and coastal management laws;

c) Establishing the legal paradigm of pancasila as a parameter of legal development in general and more specifically the legal development of marine and coastal area management.

In designing the structure of national law in general and the legal structures of marine and coastal management in particular must be guided by the ideals of law and basic values that are tabled in the Basic Law of the Republic of Indonesia Year 1945 as described above. The values raised are the cultural values of the Indonesian nation. These values are the basis for the development of national law in general and legal development of marine and coastal areas in particular that can produce social structure of Indonesian society in accordance with Pancasila and the 1945 Constitution of the Republic of Indonesia. While the required legal instruments are the legal tools capable of meeting the needs of the Indonesian people in the global era and capable of accommodating the ideals of national law in order to achieve national goals in addition to welfare with other countries. While addressing the global trend is done through the ratification of international conventions.

In line with the globalization era, all aspects described above are very supportive in the formation of national law and more specifically the formation of marine and coastal management law, but must be well planned, because in the formation and renewal of the law, aspirations that need attention are the aspirations of the superstructure, infrastructure, expectations and aspirations of the community, in addition to the legal drafting process of quality. The authors agree with Muladi's opinion that in the formation of law and law enforcement should be also characterized modern law. ${ }^{8}$ Therefore, the legal paradigm of Pancasila we need to mature and live, so that Pancasila as a philosophy can really be applied in social life and at the same time realize a just and prosperous society.

V. Lee Hamilton and Joseph Sanders, who conducted in-depth research on how to punish the Japanese nation rooted fundamentally into the Japanese social order. The unique Japanese way of punishment cannot be explained without linking and basing on the social structure of Japanese life. The Japanese are a collective society that does not see the individual as an absolute stand-alone, but always sees the individual in relation to others around him. Therefore, the life of the Japanese nation is collective and contextual. The Japanese concept of the perpetrators in law is holism. This means that an individual cannot be separated from his or her social context, as Hamilton and Sanders ${ }^{9}$ argue "a tendency not to separate out, or distinguish, the individual from the social context".

Characteristics of Japanese society as described above, making Japanese life full of harmony. In many ways, the conflict is pushed as low as possible. Legal settlement, which ends by determining who loses, is avoided as much as possible by the various mechanisms created outside the formal legal procedures provided. For the Japanese the dispute is an aberration. So according to Craig Parker, it cannot be separated from the tradition of Japanese society that emphasizes the values of the group and life accordingly.

Muladi (2005). Ekonomi Kelautan. Jakarta: PT. RajaGrafindo Persada, p. 35

9 Lee, H.V., and Hamilton, S. (1992). Every Justice. Responsibility and the individual in Japan and the United States, New Haven: Yale University Press. 


\section{Application of Balancing Principles with Diversity Accommodations in Legislation}

Since the New Order era, some of the products of drafting legislation in Indonesia seem to be getting away from the ideological spirit of the nation, even some people say ideological defects. The ideological defects are some of the products of the law and its implementation regulations until the regional regulations in the regions seem to be uprooted from the facts of the social, cultural, religious, ethnic and local norms of the archipelago that characterize indigenous peoples owned by the Indonesian nation. The facts indicate that some local laws and regulations reap protests from a group of people whose existence is not protected by the laws and regulations. In other words, the said legislation has not yet accommodated their existence, which in fact has indeed become part of another society within the unitary State of the Republic of Indonesia.

Recognition of the diversity or recognition of legal pluralism within the State of Indonesia is in accordance with Pancasila. Therefore, indigenous and tribal peoples that exist in various parts of Indonesia must be acknowledged to exist based on togetherness in diversity. Recognition of indigenous and tribal peoples with all things attached to them based on similarity in diversity does not mean that ignoring the interests of others, but based on the concept of Pancasila is to maintain a balance of all the interests that exist.

In the context of Indonesia, these principles are understood as the cultural control of the drafting of legislation. That is, the entire legal product is derived from the principles of togetherness, consensus and consensus deliberation. Of course, not only stop in the constitution like the 1945 Constitution of the State of the Republic of Indonesia, but a set of legislation starting from the law, government regulations, presidential regulations, local regulations to the lowest regulations at the village level. All of these are the norms that follow up the constitutional articles and are controlled by the nation's cultural values so that laws can be returned or returned to each culture of the Indonesian society itself and accepted. In this way, the legally preferred form of legal culture is an institutional form and indeed always shows that culture moves between two levels between what is being formed and which has been formed by the individual as well as by the State.

The theoretical implications of the existence of diversity that live within one region are equal and equally well regarded as a fact which is believed to be true there by each, of course they interact. Theoretically, the intended interaction is expected to give rise to five possible changes ${ }^{10}$, First, integration, i.e. the incorporation of law, local law and other laws; secondly, incorporation (incorporation), i.e., to partial state law into local law or vice versa; third, conflict (conflict), namely the law of the State and local law is conflicting with each other; fourth, competition (competition), namely State law, local law, and other laws running alone in accessing natural resources; fifth, avoidance, i.e. one of the existing laws avoids other legal validity.

In the conflict on the management of marine and coastal natural resources, for example, when the resources of Lusipara island are claimed by Latuhalat as part of its territory (ulayat) on the other hand, Central Maluku Regency also claims the island of Lusipara as part of the Central Maluku district. Likewise, in water resource conflicts, when water sources originate from other regions (outside districts or provinces) on the one hand,

10 Nader, L., and Harry, F.T. (1978), The Disputing Process; Law in Ten Societies. Colombia Press, p. 45 
and on the other hand their utilization by different districts or provinces from the water sources is called first, the government conflict management is based on Article 87 of Law Number 7 of 2004 on Water Resources, which is settled cross-regional government (horizontally). While article 88 of the law states:

(1) The completion of water resources at the stage pursued pursuant to the principle of deliberation for consensus;

(2) In the event that the settlement of a dispute as referred to in paragraph (1) is not obtained by agreement, the parties may seek to settle efforts outside the court or through the courts;

(3) Non-court dispute resolution efforts as referred to in paragraph (2) shall be conducted by arbitration or dispute resolution in accordance with laws and regulations.

Article 89 states that the dispute concerning the dispute over authority of water resources management between the government and local government is completed in accordance with the laws and regulations. Under conditions of exploiting natural resources cross-territorially involving two or more regional administrative units and administrations, conflicts can occur between local governments horizontally, but may also occur diagonally. This means that there can be conflicts between local governments, between local governments in one region on the one hand and local government is lower on the other, even indigenous and tribal peoples as stakeholders of water resources. While the provisions in some laws do not mention how to resolve conflicts or disputes where structurally among conflict actors differ in their structural level of authority as described above. This is blurred when for example one party demands rights based on cultural (adat) and on the other hand a structural order (juridical formal). Especially when the conflict concerns the diagonal relationship between indigenous and tribal peoples on the one hand and governments in other regions on the other hand has no structural relationship.

The impact of sectorial coastal utilization on the management of non-integrated management, there are differences in objectives, targets and plans to create rivalry and even conflict between coastal users and overlapping planning. ${ }^{11}$ Furthermore, exploitative impacts and beyond the carrying capacity of the environment are seen in the rate of physical damage of the coastal environment that is increasing from year to year. Thus, it is necessary to balance the control of marine and coastal areas by indigenous and tribal peoples in relation to the government's policy on the boundaries of the management of marine and coastal areas. In this perspective there is also an acknowledgment of recognition given by the state that can be categorized as objective recognition.

The application of the principle of balance is actually related to the welfare of society. This means that the government policy should be synergistic with the interests of the community, especially indigenous peoples. The concept of welfare is often misinterpreted by simply putting forward the physical aspects without regard to nonphysical aspects that deserve attention in every government policy. Welfare should be seen as part of the freedom to act and behave in managing the various natural resources that have been enjoyed without any pressure and disturbance from any party including the government.

11 Sunyowati, D. (2008), Kerangka Hukum Pengelolaan Wilayah Pesisir Berdasarkan Konsep Integrated Coastal Management Dalam Rangka Pembangunan Kelautan Berkelanjutan. (Dissertation). Post-graduate Airlangga University, Surabaya, p. 9 
Coastal and marine areas hold the potential of natural resources that have been centrally managed wisely and prudently by indigenous groups. Increasing population also increased the various needs of life that resulted in less healthy competition. The government as a party that is part of the common life as a nation has the responsibility to create harmonious nuances of life through various policies in the form of legislation. The responsibility of the government must be in synergy with the basic needs of the community, especially the indigenous peoples so as to create balance in a harmonious atmosphere so as not to cause too many conflicts in people's lives either vertically or horizontally.

In-depth and comprehensive studies related to the special natural resource management authority in coastal and marine areas and equitable protection of law for indigenous peoples will certainly be based on philosophical, rehired, sociological, and political values as an important reference so that it can give birth to a thought which is holistic to answer the various problems that appear with the management of natural resources on the coastal and marine areas based on the principle of balance.

Given the complexity of problems in the management of natural resources, especially marine, coastal and small island resources, an integrated approach in policy planning is a major prerequisite in ensuring the sustainability of economic, social and environmental processes in accordance with the principles contained in the rechtsidee of Pancasila which contains the principle of equilibrium. The policy and management of marine development should be a balanced integration between the ocean and land sectors and integrate in the national development strategy so that land and sea power can be utilized optimally for the welfare of the nation.

\section{Conclusion}

Under conditions of exploiting natural resources cross-territorially involving two or more regional administrative units and administrations, conflicts can occur between local governments horizontally, but may also occur diagonally. This means that there can be conflicts between local governments, between local governments in one region on the one hand and local government is lower on the other, even indigenous and tribal peoples as stakeholders of water resources. At this point there have been diagonal conflicts between local governments with formal and village management models (indigenous and tribal peoples) as owners of water resources. There needs to be a clear and precise arrangement of government authority in the management of natural resources in coastal and marine areas in a synergy with the authority of indigenous peoples, so as not to cause problems in the management of natural resources. Governments should recognize the authority of indigenous peoples in the management of natural resources in coastal and marine areas based on the principles of local wisdom and establish them in the rule of law so as to have a clear and definite power. For this reason, indigenous peoples should be viewed as an integral part of all aspects of national development, both as objects and subjects of development that must be maximally empowered so as to bring impact to the progress of nation and state development. 


\section{References}

Fakrulloh, Z.A. (2000). Wajah Hukum di Era Globalisasi. Bandung: Citra Aditya Bakti.

Lee, H.V., and Hamilton, S. (1992). Every Justice. Responsibility and the individual in Japan and the United States, New Haven: Yale University Press.

Manery, B.D., et al. (1997), Pengaruh Kebijakan Pemerintah Dalam Pengelolaan Sumberdaya Alam terhadap Kehidupan Masyarakat Adat di Provinsi Maluku. Research Paper: Pattimura University in association Yayasan Sejati Jakarta.

Muladi. (2005). Ekonomi Kelautan. Jakarta: PT. RajaGrafindo Persada.

Nader, L., and Harry, F.T. (1978), The Disputing Process; Law in Ten Societies. Colombia Press.

Notonagoro. (1982). Beberapa Hal Mengenai Falsafah Pancasila. Jakarta: Rajawali Pers.

Saleh, R. (1996). Pembinaan Cita Hukum dan Asas-asas Hukum Nasional. Jakarta: CV. Karya Dunia Fikir.

Saptenno, M.J. (2003), Kajian Yuridis tentang Pengelolaan Wilayah Pesisir dan Laut. (Paper). Ambon: Faculty of Law, Pattimura University.

Sunyowati, D. (2008), Kerangka Hukum Pengelolaan Wilayah Pesisir Berdasarkan Konsep Integrated Coastal Management Dalam Rangka Pembangunan Kelautan Berkelanjutan. (Dissertation). Post-graduate Airlangga University, Surabaya.

Wever, L., Glaser, M., Gorris, P., \& Ferrol-Schulte, D. (2012). Decentralization and participation in integrated coastal management: Policy lessons from Brazil and Indonesia. Ocean \& Coastal Management, 66, 63-72. 